\title{
Chemical Constituents of the Egg Cases of Tenodera angustipennis (Mantidis ootheca) with Intracellular Reactive Oxygen Species Scavenging Activity
}

\author{
Seung Mok Ryu ${ }^{1}$, Hyeon-hwa Nam ${ }^{1}$, Joong Sun Kim ${ }^{1}{ }^{\circledR}$, Jun-ho Song ${ }^{1}{ }^{\circledR}$, Young Hye Seo ${ }^{1}$, Hyo Seon Kim ${ }^{1}$, \\ A Yeong Lee ${ }^{1}$, Wook Jin Kim ${ }^{1}$, Dongho Lee ${ }^{2}$, Byeong Cheol Moon ${ }^{1}{ }^{1}$ and Jun Lee ${ }^{1, *(1)}$ \\ 1 Herbal Medicine Resources Research Center, Korea Institute of Oriental Medicine (KIOM), Naju 58245, Korea; \\ smryu@kiom.re.kr (S.M.R.); hhnam@kiom.re.kr (H.-h.N.); centraline@kiom.re.kr (J.S.K.); \\ songjh@kiom.re.kr (J.-h.S.); wnsl1118@kiom.re.kr (Y.H.S.); hs0320@kiom.re.kr (H.S.K.); \\ lay7709@kiom.re.kr (A.Y.L.); ukgene@kiom.re.kr (W.J.K.); bcmoon@kiom.re.kr (B.C.M.) \\ 2 Department of Plant Biotechnology, College of Life Sciences and Biotechnology, Korea University, \\ Seoul 02841, Korea; dongholee@korea.ac.kr \\ * Correspondence: junlee@kiom.re.kr; Tel.: +82-61-338-7129
}

Citation: Ryu, S.M.; Nam, H.-h.; Kim, J.S.; Song, J.-h.; Seo, Y.H.; Kim, H.S.; Lee, AY.; Kim, W.J.; Lee, D.; Moon, B.C.; et al. Chemical Constituents of the Egg Cases of Tenodera angustipennis (Mantidis ootheca) with Intracellular Reactive Oxygen Species Scavenging Activity. Biomolecules 2021, 11, 556. https:// doi.org/10.3390/biom11040556

Academic Editor: Vladimir N. Uversky

Received: 30 March 2021 Accepted: 8 April 2021

Published: 10 April 2021

Publisher's Note: MDPI stays neutral with regard to jurisdictional claims in published maps and institutional affiliations.

Copyright: (c) 2021 by the authors. Licensee MDPI, Basel, Switzerland. This article is an open access article distributed under the terms and conditions of the Creative Commons Attribution (CC BY) license (https:/ / creativecommons.org/licenses/by/ $4.0 /)$.

\begin{abstract}
As a traditional medicine with potential antioxidant effects, Tenodera angustipennis egg cases (Mantidis ootheca) are a potential source of new bioactive substances. Herein, three new $\mathrm{N}$-acetyldopamine derivatives, namely, (+)-tenoderin A (1a), (-)-tenoderin A (1) b), and tenoderin B (2), along with thirteen known compounds (3-15), were isolated from a 70\% EtOH extract of $T$. angustipennis egg cases. Compound $\mathbf{1}$ was isolated as a racemic mixture, and two enantiomers (1a and 1b) were successfully separated by chiral-phase preparative HPLC. The chemical structures of the new compounds were established by NMR spectroscopy and high-resolution electrospray ionization mass spectrometry, and the absolute configurations of enantiomers $\mathbf{1 a}$ and $\mathbf{1} \mathbf{b}$ were determined by electronic circular dichroism spectroscopy. All the new compounds exhibited antioxidant activities with $\mathrm{IC}_{50}$ values of $19.45-81.98 \mu \mathrm{M}$, as evaluated using free-radical scavenging assays, with the highest activity observed for compound $\mathbf{2}$. In addition, compounds $\mathbf{1 a}, \mathbf{1} \mathbf{b}$, and $\mathbf{2}$ exhibited inhibitory activities on intracellular reactive oxygen species generation.
\end{abstract}

Keywords: Mantidis ootheca; Tenodera angustipennis; N-Acetyldopamine derivative; tenoderin; antioxidant activity

\section{Introduction}

Mantidis ootheca, which refers to egg cases of the Mantidae family, such as Tenodera angustipennis Saussure, Hierodula patellifera Serville, Statilia maculate Thunberg, and Tenodera sinensis Saussure, has been used as a source of traditional medicines in East Asia, including Korea and China [1]. Mantidis ootheca has been used in traditional medicines to treat incontinence, lumbago, spermatorrhea, acidosis, renal failure, and leukorrhea [2], and has been reported to have various biological activities, including anti-inflammatory, antidiuretic, anticancer, and antioxidant activities, as well as vascular relaxant effects [3-6]. Although various pharmacological studies on Mantidis ootheca have been reported, only a few studies have investigated its chemical constituents. The chemical constituents of Mantidis ootheca have been revealed to include fatty acids and phenols that exhibit pharmacological properties, such as antibacterial, antibiofilm, antioxidant, and anti-atherosclerotic effects [7-9]. Notably, previous studies have indicated that commercially available Mantidis ootheca products contain the egg cases of several mantis species within one package [10]. As such mixtures may be used for research, the exact identification of research samples is of particular importance.

As part of our continuing research on the discovery of new bioactive substances in Mantidis ootheca $[10,11]$, the egg cases of T. angustipennis, which constitute a major 
raw material within Mantidis ootheca product mixtures, were selected for this study through sample identification. Using a 70\% EtOH extract of T. angustipennis egg cases, which was selected as an antioxidant resource through our screening system, three new $N$-acetyldopamine derivatives (1a, 1b, and $\mathbf{2}$ ) and thirteen known compounds (3-15) were isolated. Compound $\mathbf{1}$ was isolated as an enantiomeric mixture, and two stereoisomers (1a and 1b) were successfully separated by chiral-phase preparative HPLC. Their chemical structures were identified using spectroscopic/spectrometric techniques including NMR spectroscopy, electronic circular dichroism (ECD) spectroscopy, and high-resolution electrospray ionization mass spectrometry (HRESIMS). To assess the antioxidant activities of the isolated compounds, their free-radical 1,1-diphenyl-2-picrylhydrazyl (DPPH) and 2,2'azino-bis-3-ethylbenzthiazoline-6-sulfonic acid (ABTS) scavenging activities and their inhibitory activity on intracellular reactive oxygen species (ROS) generation were evaluated.

\section{Materials and Methods}

\subsection{General Experimental Procedures}

UV, optical rotation, and ECD spectra were recorded using a Pop UV-vis spectrophotometer (Mecasys, Daejeon, Korea), a P-2000 polarimeter (Jasco, Tokyo, Japan), and a J-1100 spectrometer (Jasco), respectively. LC/MS and HRESIMS data were acquired using a UPLC Q-TOF MS spectrometer (Waters, Milford, MA, USA). GC/MS data were recorded using an Agilent 6890/JMS-700 system (Agilent, Palo Alto, CA, USA). NMR data were acquired using a $500 \mathrm{MHz}$ NMR spectrometer (Bruker, Karlsruhe, Germany). MPLC was performed using a Biotage Selekt system (Biotage AB, Uppsala, Sweden). Preparative HPLC was performed using a Waters system with an YMC-Pack ODS-A column $(5 \mu \mathrm{m}, 250 \times 20 \mathrm{~mm}$ I.D.) and a Chiralpak IH column $(5 \mu \mathrm{m}, 250 \times 4.6 \mathrm{~mm}$ I.D. $)$.

\subsection{Insect Material}

The insect material (Mantidis ootheca) was purchased from a medicinal herb company (Gwangmyeongdang Co., Ulsan, Korea) in July 2019, authenticated, and deposited in the Korean Herbarium of Standard Herbal Resources (Index Herbarium code KIOM, specimen no. 2-20-0223) at the Korea Institute of Oriental Medicine. To prepare the sample for this study, the egg cases of T. angustipennis were identified and selected based on key morphological characteristics, such as shape, color, texture, and angle of the distal end [10]. All materials had a fusiform shape, a tapered distal end with angles of $22^{\circ}-50^{\circ}$, and a lusterless and brownish textured external wall (Figure S16).

\subsection{Extraction and Isolation}

Dried T. angustipennis egg cases (900.0 g) were ground and extracted with $70 \% \mathrm{EtOH}$ $(3 \times 10.0 \mathrm{~L})$ at room temperature. After the solvent was evaporated, the residue was suspended in distilled water $(4.0 \mathrm{~L})$ and extracted using EtOAc $(3 \times 4.0 \mathrm{~L})$ to obtain the EtOAc-soluble extract (23.6 g). The EtOAc-soluble extract (20.0 g) was fractionated by MPLC using Diaion HP20 (Mitsubishi Chemical, Tokyo, Japan) cartridges $\left(400 \mathrm{~g}, \mathrm{H}_{2} \mathrm{O}-\right.$ $\mathrm{MeOH}, 100: 0$ to $0: 100 \mathrm{in} 18 \mathrm{CV}, 40 \mathrm{~mL} / \mathrm{min}$ ) to produce six fractions (Fr 1-6). Fr 2 (1368.3 mg) was fractionated by MPLC using Sfär Silica HC (Biotage AB, Uppsala, Sweden) cartridges (200 g, n-hexane-EtOAc, 80:20 to 0:100 in $30 \mathrm{CV}, 30 \mathrm{~mL} / \mathrm{min}$ ) to produce nine sub-fractions (Fr 2.1-2.9). Fr 2.2 (3.7 mg) was purified using preparative HPLC $\left(\mathrm{H}_{2} \mathrm{O}-\mathrm{ACN}\right.$, 80:20 to 40:60 in $50 \mathrm{~min}, 6 \mathrm{~mL} / \mathrm{min})$ to yield $5(1.2 \mathrm{mg})$. Fr $2.4(44.3 \mathrm{mg})$ was purified using preparative $\mathrm{HPLC}\left(\mathrm{H}_{2} \mathrm{O}-\mathrm{ACN}, 85: 15\right.$ to $\left.70: 30 \mathrm{in} 50 \mathrm{~min}, 6 \mathrm{~mL} / \mathrm{min}\right)$ to yield 6 (23.4 mg). Fr $2.5(43.6 \mathrm{mg})$ was purified using preparative $\operatorname{HPLC}\left(\mathrm{H}_{2} \mathrm{O}-\mathrm{ACN}, 85: 15\right.$ to $70: 30$ in $\left.50 \mathrm{~min}, 6 \mathrm{~mL} / \mathrm{min}\right)$ to yield $10(14.4 \mathrm{mg})$. Fr $2.6(34.9 \mathrm{mg})$ was purified using preparative $\mathrm{HPLC}\left(\mathrm{H}_{2} \mathrm{O}-\mathrm{ACN}\right.$, 85:15 to $70: 30$ in $50 \mathrm{~min}, 6 \mathrm{~mL} / \mathrm{min})$ to yield $9(15.5 \mathrm{mg}), \mathbf{1 1}(3.2 \mathrm{mg}), \mathbf{1 2}(1.8 \mathrm{mg})$, and 13 (2.4 mg). Fr 2.9 (1648.3 mg) was fractionated by MPLC using Sephadex $\mathrm{LH}_{20}$ (Pharmacia Fine Chemicals Inc., Piscataway, NJ, USA) cartridges $\left(120 \mathrm{~g}, \mathrm{H}_{2} \mathrm{O}-\mathrm{MeOH}, 100: 0\right.$ to 0:100 in $16 \mathrm{CV}, 20 \mathrm{~mL} / \mathrm{min}$ ) to produce nine sub-fractions (Fr 2.9.1-2.9.9). Fr 2.9.3 (114.6 mg) was purified using preparative $\mathrm{HPLC}\left(\mathrm{H}_{2} \mathrm{O}-\mathrm{ACN}, 90: 10\right.$ to 80:20 in $\left.50 \mathrm{~min}, 6 \mathrm{~mL} / \mathrm{min}\right)$ to 
yield 3 (39.8 mg) and 4 (40.1 mg). Fr 2.9.5 (55.1 mg) was purified using preparative HPLC $\left(\mathrm{H}_{2} \mathrm{O}-\mathrm{ACN}, 85: 15\right.$ to $\left.75: 25 \mathrm{in} 50 \mathrm{~min}, 6 \mathrm{~mL} / \mathrm{min}\right)$ to yield $\mathbf{1}(6.3 \mathrm{mg})$. Racemic mixture 1 was separated by preparative HPLC ( $n$-hexane-EtOH-MeOH, 70:20:10 isocratic in $15 \mathrm{~min}$, $1 \mathrm{~mL} / \mathrm{min}$ ) with a chiral-phase stationary column (Chiralpak $\mathrm{IH})$ to yield $\mathbf{1 a}\left(2.0 \mathrm{mg}, t_{\mathrm{R}} 4.8\right.$ $\mathrm{min})$ and $\mathbf{1 b}\left(2.1 \mathrm{mg}, t_{\mathrm{R}} 11.7 \mathrm{~min}\right)$. Fr $4(863.9 \mathrm{mg})$ was fractionated by MPLC using Sfär Silica HC cartridges ( $100 \mathrm{~g}, \mathrm{CHCl}_{3}-\mathrm{MeOH}, 100: 0$ to $50: 50$ in $40 \mathrm{CV}, 70 \mathrm{~mL} / \mathrm{min}$ ) to produce seven sub-fractions (Fr 4.1-4.7). Fr $4.1(53.5 \mathrm{mg}$ ) was purified using preparative HPLC $\left(\mathrm{H}_{2} \mathrm{O}-\mathrm{ACN}, 80: 20\right.$ to $60: 40$ in $\left.50 \mathrm{~min}, 6 \mathrm{~mL} / \mathrm{min}\right)$ to yield $7(6.9 \mathrm{mg})$ and $8(11.2 \mathrm{mg})$. Fr $4.4(198.5 \mathrm{mg})$ was purified using preparative $\mathrm{HPLC}\left(\mathrm{H}_{2} \mathrm{O}-\mathrm{ACN}, 80: 20\right.$ to $70: 30 \mathrm{in} 50 \mathrm{~min}$, $6 \mathrm{~mL} / \mathrm{min})$ to yield $2(14.6 \mathrm{mg})$. Fr $5(2176.2 \mathrm{mg})$ was fractionated by MPLC using Sfär Silica HC cartridges ( $200 \mathrm{~g}, \mathrm{CHCl}_{3}-\mathrm{MeOH}, 100: 0$ to $50: 50$ in $21 \mathrm{CV}, 80 \mathrm{~mL} / \mathrm{min}$ ) to produce five sub-fractions (Fr 5.1-5.5). Fr 5.3 (473.7 mg) was fractionated by MPLC using Sephadex $\mathrm{LH}_{20}$ cartridges $\left(120 \mathrm{~g}, \mathrm{H}_{2} \mathrm{O}-\mathrm{MeOH}, 100: 0\right.$ to $0: 100$ in $17 \mathrm{CV}, 30 \mathrm{~mL} / \mathrm{min}$ ) to produce nine sub-fractions (Fr 5.3.1-5.3.7). Fr 5.3.2 (32.7 mg) was purified using preparative HPLC $\left(\mathrm{H}_{2} \mathrm{O}-\mathrm{ACN}, 75: 25\right.$ to $\left.65: 35 \mathrm{in} 50 \mathrm{~min}, 6 \mathrm{~mL} / \mathrm{min}\right)$ to yield $14(1.6 \mathrm{mg})$. Fr $6(9810.0 \mathrm{mg})$ was purified by MPLC using Sfär Silica HC cartridges (350 g, $n$-hexane- $\mathrm{CHCl}_{3}-\mathrm{MeOH}, 100: 0: 0$ to 50:50:0, 0:100:0 to 0:0:100 in $20 \mathrm{CV}, 50 \mathrm{~mL} / \mathrm{min}$ ) to yield 15 (2012.2 $\mathrm{mg})$.

\subsubsection{Tenoderin A (1)}

Brown gum; ${ }^{1} \mathrm{H}$ and ${ }^{13} \mathrm{C}$ NMR (500 and $125 \mathrm{MHz}, \mathrm{CD}_{3} \mathrm{OD}$ ), see Table 1; ESIMS (positive) $m / z 403[\mathrm{M}+\mathrm{H}]^{+}$; ESIMS (negative) $\mathrm{m} / z 401[\mathrm{M}-\mathrm{H}]^{-}$; HRESIMS $m / z 401.1349$ $[\mathrm{M}-\mathrm{H}]^{-}$(calcd for $\mathrm{C}_{20} \mathrm{H}_{21} \mathrm{~N}_{2} \mathrm{O}_{7}, 401.1349$ ).

Table 1. $1 \mathrm{D}$ NMR $\left({ }^{1} \mathrm{H}\right.$ and ${ }^{13} \mathrm{C}$ ) and $2 \mathrm{D}$ NMR (HMBC and COSY) data for compounds $\mathbf{1}$ and 2 in $\mathrm{CD}_{3} \mathrm{OD}$.

\begin{tabular}{|c|c|c|c|c|c|c|c|c|}
\hline \multirow[b]{2}{*}{ Position } & \multicolumn{4}{|c|}{1} & \multicolumn{4}{|c|}{2} \\
\hline & $\delta_{\mathrm{C}}$, Type $^{2}$ & $\begin{array}{l}\delta_{\mathrm{H}}, \text { Multi } \\
(J \text { in Hz })^{1}\end{array}$ & COSY & НМВС & $\delta_{\mathrm{C}}$, Type & $\begin{array}{c}\delta_{\mathrm{H}}, \text { Multi } \\
(J \text { in } \mathrm{Hz})\end{array}$ & COSY & НМВС \\
\hline 1 & $132.4, \mathrm{C}$ & & & & $132.5, \mathrm{C}$ & & & \\
\hline 2 & $116.8, \mathrm{CH}$ & $6.61, \mathrm{~d}(1.8)$ & & $3,4,6,7$ & $118.7, \mathrm{CH}$ & $6.78, \mathrm{~s}$ & & $3,4,6,7$ \\
\hline 3 & $147.4, \mathrm{C}$ & & & & $149.1, \mathrm{C}$ & & & \\
\hline 4 & $142.8, \mathrm{C}$ & & & & 144.1, C & & & \\
\hline 5 & $125.3, \mathrm{C}$ & & & & $118.1, \mathrm{CH}$ & $6.75, \mathrm{~s}$ & & $1,3,4,7^{\prime}$ \\
\hline 6 & $120.3, \mathrm{CH}$ & $6.39, \mathrm{~d}(1.9)$ & & $2,4,7,8^{\prime}$ & 131.7, C & & & \\
\hline 7 & $36.0, \mathrm{CH}_{2}$ & $2.55, \mathrm{t}(7.2)$ & 8 & $1,2,6,8$ & $33.1, \mathrm{CH}_{2}$ & $2.73, \mathrm{t}(7.0)$ & 8 & $1,2,6,8$ \\
\hline 8 & $42.2, \mathrm{CH}_{2}$ & $3.24, \mathrm{t}(7.2)$ & 7 & $1,7,9$ & $42.8, \mathrm{CH}_{2}$ & 3.30, overlap $^{3}$ & 7 & $1,7,9$ \\
\hline 9 & $173.4, \mathrm{CO}$ & & & & $173.4, \mathrm{CO}$ & & & \\
\hline 10 & 22.6, $\mathrm{CH}_{3}$ & $1.80, \mathrm{~s}$ & & 9 & $22.7, \mathrm{CH}_{3}$ & $1.83, \mathrm{~s}$ & & 9 \\
\hline $1^{\prime}$ & $128.5, \mathrm{C}$ & & & & $131.3, \mathrm{C}$ & & & \\
\hline $2^{\prime}$ & $116.7, \mathrm{CH}$ & $7.44, \mathrm{~d}(2.0)$ & & $3^{\prime}, 4^{\prime}, 6^{\prime}, 7^{\prime}$ & $134.3, \mathrm{CH}$ & $7.68, \mathrm{~d}(8.2)$ & $3^{\prime}$ & $3^{\prime}, 4^{\prime}, 6^{\prime}, 7^{\prime}$ \\
\hline $3^{\prime}$ & $146.5, \mathrm{C}$ & & & & $116.2, \mathrm{CH}$ & $6.84, \mathrm{~d}(8.3)$ & $2^{\prime}$ & $1^{\prime}, 4^{\prime}, 5^{\prime}$ \\
\hline $4^{\prime}$ & 152.6, C & & & & 164.0, C & & & \\
\hline $5^{\prime}$ & $115.9, \mathrm{CH}$ & $6.72, \mathrm{~d}(8.4)$ & $6^{\prime}$ & $1^{\prime}, 3^{\prime}, 4^{\prime}$ & $116.2, \mathrm{CH}$ & $6.84, \mathrm{~d}(8.3)$ & $6^{\prime}$ & $1^{\prime}, 3^{\prime}, 4^{\prime}$ \\
\hline $6^{\prime}$ & $123.9, \mathrm{CH}$ & 7.47, dd $(8.4,2.1)$ & $5^{\prime}$ & $2^{\prime}, 4^{\prime}, 7^{\prime}$ & $134.3, \mathrm{CH}$ & $7.68, \mathrm{~d}(8.2)$ & $5^{\prime}$ & $2^{\prime}, 4^{\prime}, 5^{\prime}, 7^{\prime}$ \\
\hline $7^{\prime}$ & 196.3, CO & & & & 199.1, CO & & & \\
\hline $8^{\prime}$ & $54.4, \mathrm{CH}$ & $6.66, \mathrm{~s}$ & & $4,5,6,7^{\prime}, 9^{\prime}$ & & & & \\
\hline $9^{\prime}$ & $173.2, \mathrm{CO}$ & & & & & & & \\
\hline $10^{\prime}$ & $22.4, \mathrm{CH}_{3}$ & $2.02, \mathrm{~s}$ & & $9^{\prime}$ & & & & \\
\hline
\end{tabular}

(+)-tenoderin A (1a)

Brown gum; $[\alpha]^{26}{ }_{\mathrm{D}}+21.2(c$ 0.01, $\mathrm{MeOH}) ; \mathrm{UV}(\mathrm{MeOH}) \lambda_{\max }(\log \varepsilon) 215$ (3.91), 285 (3.37), 332 (3.23) nm; ECD (c $0.5 \mathrm{mM}, \mathrm{MeOH}) \Delta \varepsilon+33.9$ (212), -19.5 (248), +20.1 (282), +7.6 (302), +11.3 (317). 
(-)-tenoderin A (1b)

Brown gum; $[\alpha]^{26}{ }_{D}-21.0(c 0.01, \mathrm{MeOH}) ; \mathrm{UV}(\mathrm{MeOH}) \lambda_{\max }(\log \varepsilon) 215$ (3.91), 285 (3.36), 332 (3.25) nm; ECD ( c $0.5 \mathrm{mM}, \mathrm{MeOH}) \Delta \varepsilon-36.6$ (212), +8.1 (247), -25.1 (284), -12.6 (302), -13.1 (317).

\subsubsection{Tenoderin B (2)}

Brown gum; UV (MeOH) $\lambda_{\max }(\log \varepsilon) 215$ (3.95), 285 (3.91) nm; ${ }^{1} \mathrm{H}$ and ${ }^{13} \mathrm{C}$ NMR (500 and $125 \mathrm{MHz}, \mathrm{CD}_{3} \mathrm{OD}$ ), see Table 1 ; ESIMS (positive) $\mathrm{m} / z 316[\mathrm{M}+\mathrm{H}]^{+}$; ESIMS (negative) $m / z 314[\mathrm{M}-\mathrm{H}]^{-}$; HRESIMS m/z $314.1042[\mathrm{M}-\mathrm{H}]^{-}$(calcd for $\mathrm{C}_{17} \mathrm{H}_{16} \mathrm{NO}_{5}, 314.1028$ ).

\subsection{Computational Methods}

ECD calculations were performed for $\mathbf{1 a}$ and $\mathbf{1 b}$. A conformer distribution was constructed using the Spartan'14 software (Wavefunction, Inc., Irvine, CA, USA) with a Merck molecular force field. The conformers were optimized at the DFT [B3LYP/6$31+G(d, p)]$ level, and ECD calculations were performed at the TDDFT (CAM-B3LYP/SVP) level with a CPCM solvent model in $\mathrm{MeOH}$ using the Gaussian 09 software (Gaussian, Inc., Wallingford, CT, USA).

\subsection{DPPH and ABTS Radical Scavenging Activities}

The DPPH (Sigma-Aldrich, St. Louis, MO, USA) and ABTS (Sigma-Aldrich) freeradical scavenging activities were measured according to previous studies [12,13]. All measurements were independently repeated three times. The DPPH and ABTS scavenging activities were calculated as follows: DPPH or ABTS scavenging activity $(\%)=[\mathrm{A}($ free radical) $-\mathrm{A}($ standard) $] / \mathrm{A}$ (free radical), where $\mathrm{A}$ is the absorbance value of DPPH at $517 \mathrm{~nm}$ or ABTS at $734 \mathrm{~nm}$.

\subsection{Detection of Intracellular ROS}

The HUVECs used in the ROS scavenging experiments were purchased from the American Type Culture Collection (ATCC, Manassas, VA, USA). The cells were cultured in $\alpha$-MEM medium, and $20 \%$ FBS in a humid atmosphere of $5 \% \mathrm{CO}_{2}$ at $37^{\circ} \mathrm{C}$.

To confirm the antioxidant effect of each compound against oxidative stress, the cells were treated with each sample at a concentration of 5, 10, 50 or $100 \mu \mathrm{M}$ and hydrogen peroxide $(1 \mathrm{mM})$, cultured for $24 \mathrm{~h}$, washed with PBS, and treated with $100 \mu \mathrm{M}$ DCFDA (ThermoFisher, Waltham, MA, USA) for $30 \mathrm{~min}$ at $37^{\circ} \mathrm{C}$. Reacted. After DCFDA was removed, and the amount of DCFDA remaining in the cells was observed using a fluorescence microscope. The fluorescence intensity at an excitation wavelength of $485 \mathrm{~nm}$ and an emission wavelength of $520 \mathrm{~nm}$ was measured using a microplate reader.

\section{Results and Discussion}

Dried T. angustipennis egg cases selected from a commercial Mantidis ootheca material were ground and extracted with $70 \% \mathrm{EtOH}$. Following fractionation, fifteen compounds were isolated from the extract and structural determination was performed (Figure 1). 
<smiles>CC(=O)NCCc1cc(O)c(O)c(C(NC(C)=O)C(=O)c2ccc(O)c(O)c2)c1</smiles>

1a: 8 'S

1b: $8^{\prime} R$<smiles>[R]c1ccc([R])c([R])c1</smiles>

5: $\mathrm{R}_{1}=\mathrm{OH}, \mathrm{R}_{2}=\mathrm{H}, \mathrm{R}_{3}=\mathrm{CHO}$

6: $\mathrm{R}_{1}=\mathrm{OH}, \mathrm{R}_{2}=\mathrm{H}, \mathrm{R}_{3}=\mathrm{COOH}$

7: $\mathrm{R}_{1}=\mathrm{OH}, \mathrm{R}_{2}=\mathrm{OCH}_{3}, \mathrm{R}_{3}=\mathrm{COCH}_{3}$

8: $R_{1}=H, R_{2}=H, R_{3}=\mathrm{COOH}$

9: $\mathrm{R}_{1}=\mathrm{OH}, \mathrm{R}_{2}=\mathrm{OH}, \mathrm{R}_{3}=\mathrm{COOH}$

10: $\mathrm{R}_{1}=\mathrm{OH}, \mathrm{R}_{2}=\mathrm{H}, \mathrm{R}_{3}=\mathrm{CH}_{2} \mathrm{COOH}$

11: $\mathrm{R}_{1}=\mathrm{OH}, \mathrm{R}_{2}=\mathrm{H}, \mathrm{R}_{3}=\mathrm{CHOHCH}_{2} \mathrm{OH}$

12: $R_{1}=O H, R_{2}=H, R_{3}=C_{C O C O N H}$<smiles>CC(=O)NCCc1cc(O)c(O)cc1C(=O)c1ccc(O)cc1</smiles>

2<smiles>O=C1C=C(c2ccc(O)cc2)C(O)O1</smiles>

13<smiles>CC(=O)NCCc1ccc(O)c(O)c1</smiles>

3<smiles>CC(=O)NCC(=O)c1ccc(O)c(O)c1</smiles>

4<smiles>COc1cc2ccc(=O)oc2cc1OC</smiles>

14<smiles>CCCCC/C=C\CCCCCCCC(=O)O</smiles>

15

Figure 1. All isolated compounds from a 70\% EtOH extract of T. angustipennis egg cases.

Compound $\mathbf{1}$ was obtained as a brown gum, and HRESIMS analysis revealed its elemental formula to be $\mathrm{C}_{20} \mathrm{H}_{22} \mathrm{~N}_{2} \mathrm{O}_{7}$, suggesting eleven degrees of unsaturation. The ${ }^{1} \mathrm{H}$ NMR data indicated the presence of two methyl groups $\left(\delta_{\mathrm{H}} 1.80\left(3 \mathrm{H}, \mathrm{s}, \mathrm{CH}_{3}-10\right)\right.$ and 2.02 $\left.\left(3 \mathrm{H}, \mathrm{s}, \mathrm{CH}_{3}-10^{\prime}\right)\right)$, two methylene groups $\left(\delta_{\mathrm{H}} 2.55(2 \mathrm{H}, \mathrm{t}, J=7.2 \mathrm{~Hz}, \mathrm{H}-7)\right.$ and $3.24(2 \mathrm{H}$, $\mathrm{t}, J=7.2 \mathrm{~Hz}, \mathrm{H}-8))$, a methine group $\left(\delta_{\mathrm{H}} 6.66\left(1 \mathrm{H}, \mathrm{s}, \mathrm{H}-8^{\prime}\right)\right)$, two meta-coupled aromatic methine groups $\left(\delta_{\mathrm{H}} 6.61(1 \mathrm{H}, \mathrm{d}, J=1.8 \mathrm{~Hz}, \mathrm{H}-2)\right.$ and $\left.6.39(1 \mathrm{H}, \mathrm{d}, J=1.9 \mathrm{~Hz}, \mathrm{H}-6)\right)$, and three aromatic methine groups in an $\mathrm{ABX}$ spin system $\left(\delta_{\mathrm{H}} 6.72\left(1 \mathrm{H}, \mathrm{d}, J=8.4 \mathrm{~Hz}, \mathrm{H}-5^{\prime}\right)\right.$, $7.44\left(1 \mathrm{H}, \mathrm{d}, J=2.0 \mathrm{~Hz}, \mathrm{H}-2^{\prime}\right)$, and $\left.7.47\left(1 \mathrm{H}, \mathrm{dd}, J=8.4,2.1 \mathrm{~Hz}, \mathrm{H}-6^{\prime}\right)\right)$ (Table 1). The ${ }^{13} \mathrm{C}$ NMR data corresponded to 20 carbons, including two methyl carbons, two methylene carbons, six methine carbons, three carbonyl carbons, and seven additional quaternary carbons (Table 1). The ${ }^{1} \mathrm{H}$ and ${ }^{13} \mathrm{C}$ NMR data for compound 1 were similar to those for the dimeric $N$-acetyldopamine derivative polyrhadopamine B [14], except that the 2-oxo- $\mathrm{N}$-acetyldopamine (4) unit linked at C-6 in polyrhadopamine B was linked at C-5 in compound 1 . This result was supported by the presence of two doublet proton signals with meta coupling at $\mathrm{H}-2\left(\delta_{\mathrm{H}} 6.61\right)$ and $\mathrm{H}-6\left(\delta_{\mathrm{H}} 6.39\right)$, as well as the $\mathrm{HMBC}$ correlations between H-6/C-8 $\left(\delta_{\mathrm{C}} 54.4\right), \mathrm{C}-7\left(\delta_{\mathrm{C}} 36.0\right), \mathrm{C}-2\left(\delta_{\mathrm{C}} 116.8\right)$, and $\mathrm{C}-4\left(\delta_{\mathrm{C}} 142.8\right)$ and those between $\mathrm{H}-8^{\prime} / \mathrm{C}-6\left(\delta_{\mathrm{C}} 120.3\right), \mathrm{C}-4\left(\delta_{\mathrm{C}} 142.8\right), \mathrm{C}-5\left(\delta_{\mathrm{C}} 125.3\right), \mathrm{C}-9^{\prime}\left(\delta_{\mathrm{C}} 173.2\right)$, and C-7 ${ }^{\prime}\left(\delta_{\mathrm{C}}\right.$ 196.3) (Figure 2). 


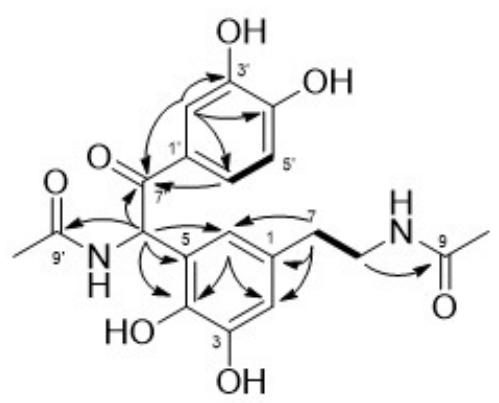

1

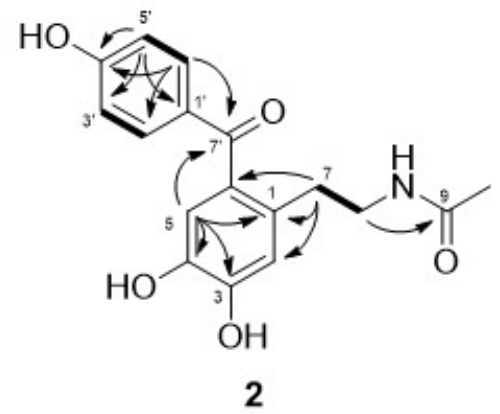

2

Figure 2. Key HMBC (arrow) and COSY (bold) correlations (1 and 2).

Compound $\mathbf{1}$ is a racemic mixture, which was suggested by the lack of an optical rotation value. Therefore, chiral separation was performed on a Chiralpak IH column to yield optically pure enantiomers $\mathbf{1 a}(+21.2(c 0.01, \mathrm{MeOH}))$ and $\mathbf{1} \mathbf{b}(-21.0(c 0.01, \mathrm{MeOH}))$ (Figure 3). The absolute configurations of $\mathbf{1 a}$ and $\mathbf{1 b}$ were determined by comparing the calculated and experimental ECD spectra. The calculated ECD spectra of the $8^{\prime} R$ and $8^{\prime} S$ stereoisomers were in good agreement with the experimental spectra of $\mathbf{1 a}$ and $\mathbf{1} \mathbf{b}$, respectively (Figure 4). Therefore, the structures of new compounds $\mathbf{1 a}$ and $\mathbf{1} \mathbf{b}$ were assigned as (+)-tenoderin A and (-)-tenoderin A, respectively.

(A)

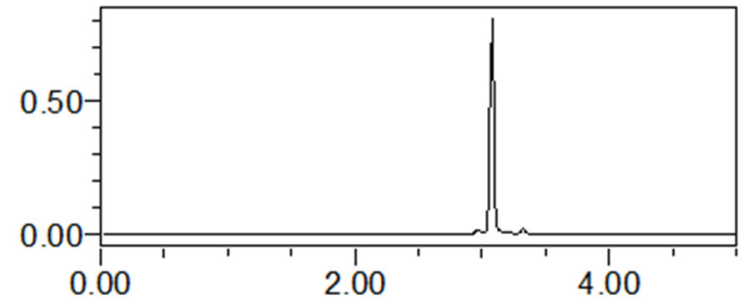

(B)



$\begin{array}{ccc}\text { Retention Time }\left(t_{R}\right) & \text { Peak Area } & \text { \% Area } \\ 4.8 \mathrm{~min} & 8365076 & 50.3 \\ 11.7 \mathrm{~min} & 8258754 & 49.7\end{array}$

Figure 3. (A) UPLC chromatogram of compound $\mathbf{1}$ (stationary phase: ACQUITY UPLC BEH $\mathrm{C}_{18}$ column $(2.1 \mathrm{~mm} \times 100 \mathrm{~mm}, 1.7 \mu \mathrm{m})$; mobile phase: $\mathrm{H}_{2} \mathrm{O}-\mathrm{ACN}, 95: 5$ to $50: 50$ in $5 \mathrm{~min}, 0.3 \mathrm{~mL} / \mathrm{min}$; UV $280 \mathrm{~nm}$ ). (B) HPLC chromatogram of the enantiomeric mixture of compound 1 (stationary phase: Chiralpak IH column ( $4.6 \mathrm{~mm} \times 250 \mathrm{~mm}, 5 \mu \mathrm{m})$; mobile phase: $n$-hexane-EtOH-MeOH, 70:20:10 isocratic in $15 \mathrm{~min}, 1 \mathrm{~mL} / \mathrm{min}$; UV $280 \mathrm{~nm}$ ). 


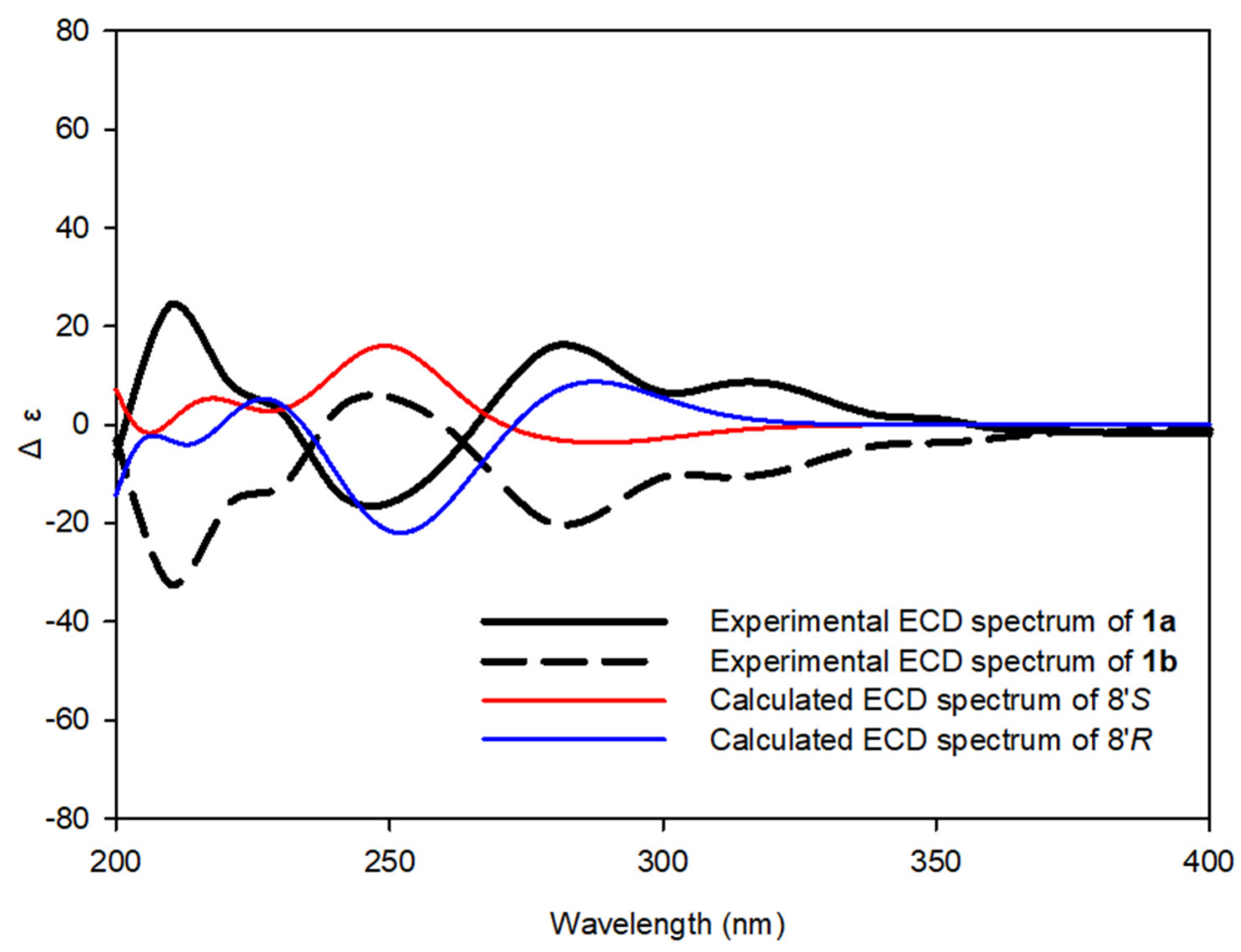

Figure 4. Calculated and experimental electronic circular dichroism (ECD) spectra of $\mathbf{1 a}$ and $\mathbf{1 b}$.

Compound $\mathbf{2}$ was obtained as a brown gum, and its elemental formula was determined to be $\mathrm{C}_{17} \mathrm{H}_{17} \mathrm{NO}_{5}$ using HRESIMS analysis. The 1D NMR data revealed the presence of a $\mathrm{N}$-acetyldopamine (3) moiety as well as a 1,4-disubstituted benzene ring $\left(\delta_{\mathrm{H}} 7.68(2 \mathrm{H}, \mathrm{d}\right.$, $J=8.2 \mathrm{~Hz}, \mathrm{CH}_{3}-2^{\prime}$ and $\left.6^{\prime}\right)$ and $6.84\left(2 \mathrm{H}, \mathrm{d}, J=8.3 \mathrm{~Hz}, \mathrm{CH}_{3}-3^{\prime}\right.$ and $\left.5^{\prime}\right) ; \delta_{\mathrm{C}} 134.3\left(\mathrm{C}-2^{\prime}\right.$ and $\left.6^{\prime}\right)$ and $116.2\left(\mathrm{C}-3^{\prime}\right.$ and $\left.\left.5^{\prime}\right)\right)$ and a ketone group $\left(\delta_{\mathrm{C}} 199.1\left(\mathrm{C}-7^{\prime}\right)\right)($ Table 1$)$. A detailed analysis of the NMR data showed that compound 2 was similar to periplanetol A [15], except for the absence of a hydroxy group at C- $5^{\prime}$ and the presence of an aromatic methine signal $\left(\delta_{\mathrm{H}}\right.$ $\left.6.84, \mathrm{H}-5^{\prime}\right)$ for compound 2 . These results are supported by the COSY correlations between $\mathrm{H}-5^{\prime} / \mathrm{H}-6^{\prime}$ and the HMBC correlations between H-5 / C-4 $4^{\prime}\left(\delta_{\mathrm{C}} 164.0\right), \mathrm{C}-3^{\prime}\left(\delta_{\mathrm{C}} 116.2\right)$, and $\mathrm{C}-1^{\prime}\left(\delta_{\mathrm{C}} 131.3\right)$ (Figure 2). Accordingly, the structure of new compound 2 was elucidated, and this compound was given the trivial name tenoderin B.

In addition to the above-described new compounds, thirteen known compounds (3-15) were isolated and identified as $\mathrm{N}$-acetyldopamine (3), 2-oxo- $\mathrm{N}$-acetyldopamine (4) [16], 4-hydroxybenzaldehyde (5) [17], 4-hydroxybenzoic acid (6) [18], apocynin (7) [19], benzoic acid (8) [20], protocatechuic acid (9) [21], 4-hydroxyphenylacetic acid (10) [22], (S)-1-phenylenthane-1,2-diol (11) [23], 4-hydroxyphenylglyoxylic acid amide (12) [24], ( \pm )hydroxybutenolide (13) [25], scoparone (14) [26], and oleic acid (15) (Figure 1). Notably, many of the known compounds (4-14) were first isolated from Mantidis ootheca.

The antioxidant activity of the extract, as measured using DPPH and ABTS radical scavenging assays, was significant $(81.99 \pm 1.98 \%$ and $99.74 \% \pm 0.13 \%$, respectively, at $100 \mu \mathrm{g} / \mathrm{mL}$ ) (Table S1). Furthermore, all the isolated compounds were screened for antioxidant activity at a concentration of $100 \mu \mathrm{M}$ using DPPH and ABTS radical scavenging assays. DPPH and ABTS radical scavenging activities were observed for compounds $\mathbf{1 a}, \mathbf{1} \mathbf{b}$, $\mathbf{2}, \mathbf{3}, \mathbf{4}$, and $\mathbf{9}$ (Table S1). In particular, new compounds $\mathbf{1 a}, \mathbf{1} \mathbf{b}$, and $\mathbf{2}$ displayed antioxidant activities with $\mathrm{IC}_{50}$ values between 19.45 and $81.98 \mu \mathrm{M}$. Among the new compounds, the antioxidant activity of compound $\mathbf{2}$ was the highest. In addition, although compounds $\mathbf{1 a}$ and $\mathbf{1 b}$ were enantiomers, there was a difference in their antioxidant activities (Table 2). Compound $\mathbf{1 b}$ exhibited stronger antioxidant effects than $\mathbf{1 a}$, and the ratios of their $\mathrm{IC}_{50}$ values were 1:1.8 (DPPH) and 1:1.3 (ABTS). These results suggest that the difference in antioxidant activity between the two enantiomers is due to the chirality of C-8'. 
Table 2. IC 50 values for the antioxidant activities of new compounds $\mathbf{1 a}, \mathbf{1} \mathbf{b}$, and $\mathbf{2}$.

\begin{tabular}{ccc}
\hline \multirow{2}{*}{ Samples } & \multicolumn{2}{c}{ IC $_{\mathbf{5 0}}(\boldsymbol{\mu M})$} \\
\cline { 2 - 3 } & DPPH & ABTS \\
\hline 1a & $81.50 \pm 0.77^{1}$ & $81.98 \pm 0.48$ \\
1b & $46.54 \pm 0.56$ & $62.74 \pm 0.69$ \\
2 & $19.45 \pm 0.42$ & $37.23 \pm 0.26$ \\
Gallic acid & $8.95 \pm 0.20$ & $10.82 \pm 0.97$ \\
\hline
\end{tabular}

${ }^{1}$ Values are reported as mean $\pm \operatorname{SD}(\mathrm{n}=3)$.

In addition, to determine whether the antioxidant activities were associated with protective effects in $\mathrm{H}_{2} \mathrm{O}_{2}$-treated human umbilical vein/vascular endothelium cells (HUVECs), intracellular $2^{\prime}, 7^{\prime}$-dichlorofluorescin diacetate (DCFDA) levels were measured. Oxidative-stress-induced cell damage has been implicated in various types of disease. $\mathrm{H}_{2} \mathrm{O}_{2}$ is a major ROS produced intracellularly during pathological processes and causes oxidative injury. $\mathrm{H}_{2} \mathrm{O}_{2}$ has been extensively used as an inducer of oxidative stress for in vitro models [27]. Therefore, $\mathrm{H}_{2} \mathrm{O}_{2}$ was selected to promote oxidative stress in the current investigation. In this study, as shown in Figure 5, $\mathrm{H}_{2} \mathrm{O}_{2}$ significantly increased the intracellular DCFDA level. In this assay system, compound 2 showed a potent antioxidant activity in a dose-dependent manner and compounds $\mathbf{1 a}$ and $\mathbf{1} \mathbf{b}$ also showed significant antioxidant activity, which presented the identical activity pattern supporting the results in the free-radical scavenging assay.

(A)
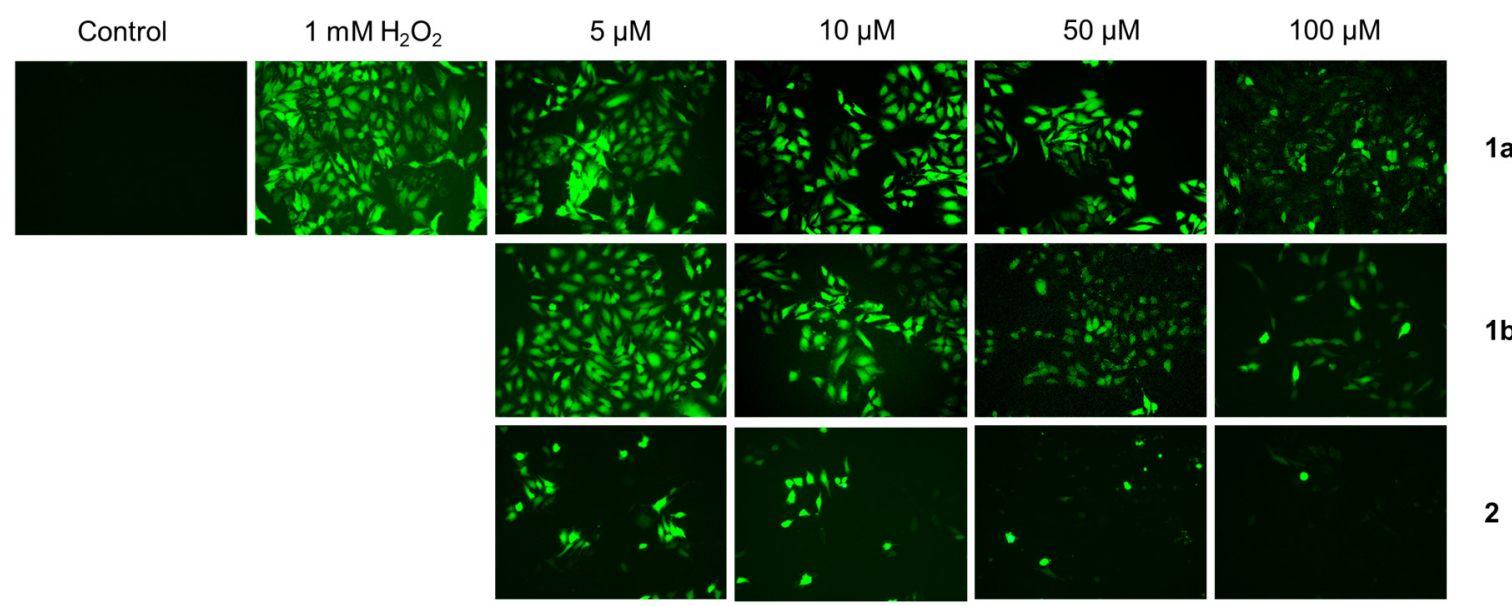

(B)

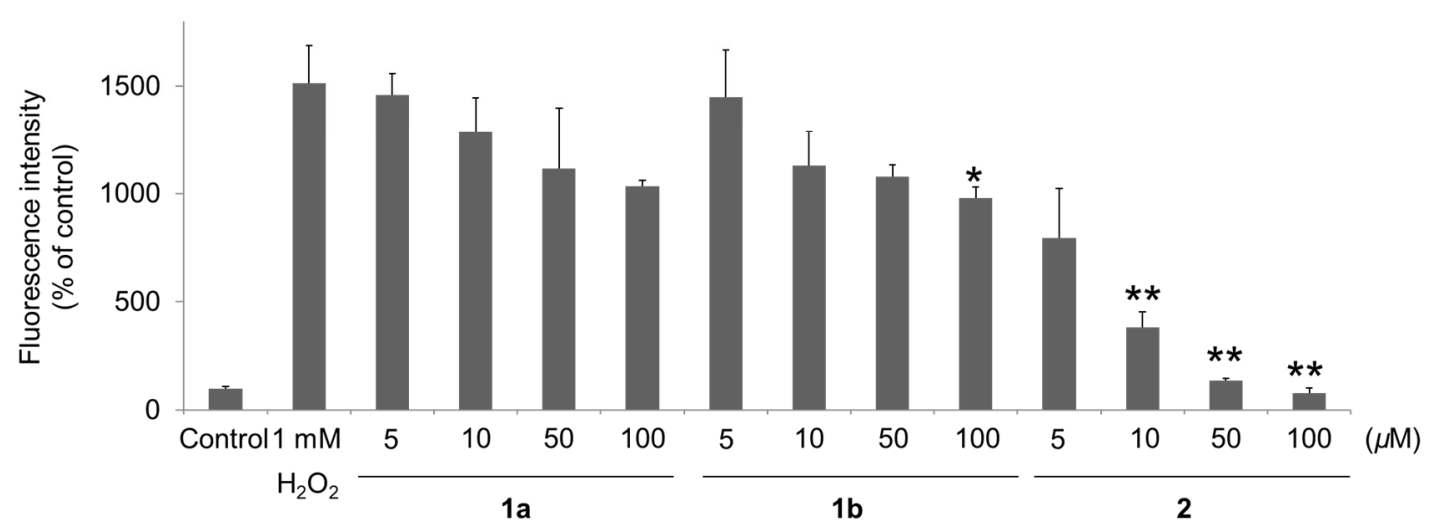

Figure 5. (A) Reactive oxygen species (ROS) scavenging activities as revealed by images of human umbilical vein/vascular endothelium cells (HUVECs) with $2^{\prime}, 7^{\prime}$-dichlorofluorescin diacetate (DCFDA) treated with 5-100 $\mu \mathrm{M}$ of compound 1a, 1b, or 2. (B) Scavenging percentages of the tested compounds. ${ }^{*} p<0.05,{ }^{* *} p<0.01$. 


\section{Conclusions}

In conclusion, this study on the chemical constituents of T. angustipennis egg cases (Mantidis ootheca) revealed sixteen compounds, including three new $\mathrm{N}$-acetyldopamine derivatives (1a, $\mathbf{1} \mathbf{b}$, and $\mathbf{2}$ ) and thirteen known compounds (3-15). Two enantiomers (1a and $\mathbf{1 b}$ ) were successfully separated by chiral-phase preparative HPLC, and the absolute configurations were determined by ECD spectroscopy. All the isolated compounds were evaluated for antioxidant activity, and the new compounds appeared to show antioxidant effects in HUVECs. These findings not only reveal various chemical constituents in the egg cases of $T$. angustipennis, they also provide guidance for clarifying the pharmacodynamic basis of the antioxidant effects of Mantidis ootheca.

Supplementary Materials: The following are available online at https:/ /www.mdpi.com/article/10 .3390/biom11040556/s1, Figure S1: Structures of known compounds (3-15), Figure S2: Spectroscopic data of known compounds (3-14), Figure S3: GC-MS spectrum of compound 15, Figure S4: 1H NMR spectrum of tenoderin $\mathrm{A}(\mathbf{1})\left(\mathrm{CD}_{3} \mathrm{OD}, 500 \mathrm{MHz}\right)$, Figure $\mathrm{S5}:{ }^{13} \mathrm{C}$ NMR spectrum of tenoderin A (1) $\left(\mathrm{CD}_{3} \mathrm{OD}, 125 \mathrm{MHz}\right)$, Figure S6: HSQC NMR spectrum of tenoderin A (1) $\left(\mathrm{CD}_{3} \mathrm{OD}\right)$, Figure S7: HMBC NMR spectrum of tenoderin A (1) $\left(\mathrm{CD}_{3} \mathrm{OD}\right)$, Figure S8: COSY NMR spectrum of tenoderin $\mathrm{A}(\mathbf{1})\left(\mathrm{CD}_{3} \mathrm{OD}\right)$, Figure S9: HRESIMS spectrum of tenoderin A (1) $\left(\mathrm{CD}_{3} \mathrm{OD}\right)$, Figure S10: ${ }^{1} \mathrm{H} N \mathrm{NR}$ spectrum of tenoderin B (2) $\left(\mathrm{CD}_{3} \mathrm{OH}, 500 \mathrm{MHz}\right)$, Figure S11: ${ }^{13} \mathrm{C}$ NMR spectrum of tenoderin B (2) $\left(\mathrm{CD}_{3} \mathrm{OH}, 125 \mathrm{MHz}\right)$, Figure S12: HSQC NMR spectrum of tenoderin B (2) $\left(\mathrm{CD}_{3} \mathrm{OH}\right)$, Figure S13: HMBC NMR spectrum of tenoderin B (2) $\left(\mathrm{CD}_{3} \mathrm{OH}\right)$, Figure S14: COSY NMR spectrum of tenoderin B (2) $\left(\mathrm{CD}_{3} \mathrm{OH}\right)$, Figure S15: HRESIMS spectrum of tenoderin B (2), Figure S16: Stereomicroscope micrographs showing the ootheca morphology of Tenodera angustipennis. (A) Dorsal view; (B) Lateral view; (C) Surface pattern on lateral view; Scale bars $=1 \mathrm{~cm}(\mathrm{~A}, \mathrm{~B}) .1 \mathrm{~mm}$ (C), Table S1: Screening of the antioxidant activity of extract $(100 \mu \mathrm{g} / \mathrm{mL})$ and isolated compounds $(100 \mu \mathrm{M})$.

Author Contributions: S.M.R. and J.L. conceived and designed the experiments; S.M.R., H.-h.N., J.S.K., and J.-h.S. performed the experiments; S.M.R., Y.H.S., H.S.K., A.Y.L., W.J.K., and D.L. analyzed the data; B.C.M. and J.L. reviewed and edited the manuscript. All authors have read and agreed to the published version of the manuscript.

Funding: This work was supported by a grant on the Development of Sustainable Application for Standard Herbal Resources (KSN2012320) from the Korea Institute of Oriental Medicine, Korea.

Institutional Review Board Statement: Not applicable.

Informed Consent Statement: Not applicable.

Data Availability Statement: Not applicable.

Acknowledgments: In this section, you can acknowledge any support given which is not covered by the author contribution or funding sections. This may include administrative and technical support, or donations in kind (e.g., materials used for experiments).

Conflicts of Interest: The authors declare no conflict of interest.

\section{References}

1. Defining Dictionary for Medicinal Herbs. Korea Institute of Oriental Medicine. Available online: http://boncho.kiom.re.kr/codex (accessed on 4 April 2019).

2. Kim, C.M.; Shin, M.K.; Ahn, D.K.; Lee, K.S. Chinese Medicine Dictionary; Jungdam: Seoul, Korea, 2006; Volume 5, pp. $2184-2186$.

3. Tan, Z.; Lei, Y.; Zhang, B.; Huang, L. Comparison of Pharmacological Studies on Ootheca Mantidis. China J. Chin. Mater. Med. 1997, 22, 496-499.

4. Kim, H.Y.; Lee, Y.J.; Han, B.H.; Yoon, J.J;; Ahn, Y.M.; Hong, M.H.; Tan, R.; Kang, D.G.; Lee, H.S. Mantidis Ootheca Induces Vascular Relaxation through Pi3k/Akt-Mediated Nitric Oxid-Cyclic Gmp-Protein Kinase G Signaling in Endothelial Cells. J. Physiol. Pharmacol. 2017, 68, 215-221. [PubMed]

5. Ahn, M.Y.; Ryu, K.S.; Lee, Y.W.; Kim, Y.S. Cytotoxicity and L-Amino Acid Oxidase Activity of Crude Insect Drugs. Arch. Pharmacal Res. 2000, 23, 477-481. [CrossRef] [PubMed]

6. Park, G.; Moon, B.C.; Lim, H. Effects of 14 Chung-Bu Medicinal Materials Described in the Dongui Bogam on Inflammatory Cytokines Production in Hacat Keratinocytes. J. Soc. Cosmet. Sci. Korea 2020, 46, 195-204. 
7. Wang, W.; Zhang, N.; Chanda, W.; Liu, M.; UD Din, S.R.; Diao, Y.; Liu, L.; Cao, J.; Wang, X.; Li, X. Antibacterial and Anti-Biofilm Activity of the Lipid Extract from Mantidis Ootheca on Pseudomonas aeruginosa. J. Zhejiang Univ. Sci. B 2018, 19, 364-371. [CrossRef]

8. Xu, M. Study of the Anti-Dpph Free Radical Component from Mantidis Ootheca Extracts. J. Anhui Agric. Univ. 2014, 2014, $11619-11620$.

9. Xu, M. Anti-Atherosclerotic Activities of Two Compounds from Mantidis Ootheca. J. Anhui Agric. Univ. 2012, 2012, 15722-15723.

10. Song, J.; Cha, J.; Moon, B.C.; Kim, W.J.; Yang, S.; Choi, G. Mantidis Oötheca (Mantis Egg Case) Original Species Identification Via Morphological Analysis and DNA Barcoding. J. Ethnopharmacol. 2020, 252, 112574-112584. [CrossRef]

11. Lim, H.; Seo, Y.S.; Ryu, S.M.; Moon, B.C.; Choi, G.; Kim, J. Two-Week Repeated Oral Dose Toxicity Study of Mantidis Ootheca Water Extract in C57bl/6 Mice. J. Evid. Based Complementary Altern. Med. 2019, 2019, 6180236. [CrossRef]

12. Kedare, S.B.; Singh, R.P. Genesis and Development of Dpph Method of Antioxidant Assay. J. Food Sci. Technol. 2011, 48, 412-422. [CrossRef]

13. Rajurkar, N.S.; Hande, S.M. Estimation of Phytochemical Content and Antioxidant Activity of Some Selected Traditional Indian Medicinal Plants. Indian J. Pharm. Sci. 2011, 73, 146-151. [CrossRef] [PubMed]

14. Tang, J.; Zhang, L.; Jiang, L.; Di, L.; Yan, Y.; Tu, Z.; Yang, C.; Zuo, Z.; Hou, B.; Xia, H.; et al. Dopamine Derivatives from the Insect Polyrhachis Dives as Inhibitors of Rock1/2 and Stimulators of Neural Stem Cell Proliferation. Tetrahedron 2014, 70, 8852-8857. [CrossRef]

15. Bai, H.; Li, Y.; Qin, F.; Yan, Y.; Wang, S.; Zhang, H.; Cheng, Y. Periplanetols A-F, Phenolic Compounds from Periplaneta Americana with Potent Cox-2 Inhibitory Activity. Fitoterapia 2020, 143, 104589. [CrossRef]

16. Noda, N.; Kubota, S.; Miyata, Y.; Miyahara, K. Optically Active N-Acetyldopamine Dimer of the Crude Drug "Zentai," the Cast-Off Shell of the Cicada Cryptotympana sp. Chem. Pharm. Bull. 2000, 48, 1749-1752. [CrossRef]

17. Kim, H.; Ralph, J.; Lu, F.; Ralph, S.A.; Boudet, A.M.; MacKay, J.J.; Sederoff, R.R.; Ito, T.; Kawai, S.; Ohashi, H. Nmr Analysis of Lignins in Cad-Deficient Plants. Part 1. Incorporation of Hydroxycinnamaldehydes and Hydroxybenzaldehydes into Lignins. Org. Biomol. Chem. 2003, 1, 268-281. [CrossRef] [PubMed]

18. Jia, J.; Jiang, C.; Zhang, X.; Jiang, Y.; Ma, D. Cui-Catalyzed Hydroxylation of Aryl Bromides under the Assistance of 5-Bromo-2(1h-Imidazol-2-Yl) Pyridine and Related Ligands. Tetrahedron Lett. 2011, 52, 5593-5595. [CrossRef]

19. Luo, J.; Ma, Q.; Zhao, Y.; Yi, T.; Li, C.; Zhou, J. Palaeophytochemical Components from the Miocene-Fossil Wood of Pinus Griffithii. J. Chin. Chem. Soc. 2009, 56, 600-605. [CrossRef]

20. Bonaparte, A.C.; Betush, M.P.; Panseri, B.M.; Mastarone, D.J.; Murphy, R.K.; Murphree, S.S. Novel Aerobic Oxidation of Primary Sulfones to Carboxylic Acids. Org. Lett. 2011, 13, 1447-1449. [CrossRef] [PubMed]

21. Matsui, T.; Kudo, A.; Tokuda, S.; Matsumoto, K.; Hosoyama, H. Identification of a New Natural Vasorelaxatant Compound,(+)Osbeckic Acid, from Rutin-Free Tartary Buckwheat Extract. J. Agric. Food Chem. 2010, 58, 10876-10879. [CrossRef] [PubMed]

22. Milne, J.E.; Storz, T.; Colyer, J.T.; Thiel, O.R.; Dilmeghani Seran, M.; Larsen, R.D.; Murry, J.A. Iodide-Catalyzed Reductions: Development of a Synthesis of Phenylacetic Acids. J. Org. Chem. 2011, 76, 9519-9524. [CrossRef]

23. Chang, L.; Ouyang, L.M.; Xu, Y.; Pan, J.; Xu, J.H. Highly Enantioselective Hydrolysis of Phenyl-1, 2-Ethanediol Cyclic Carbonates by Newly Isolated Bacillus Sp. Ecu0015. J. Mol. Catal. B Enzym. 2010, 66, 95-100. [CrossRef]

24. Matsuki, Y.; Ito, T.; Komatsu, S.; Nambara, T. Studies on the Metabolism of Atenolol. Characterization and Determination of a New Urinary Metabolite in the Rat. Chem. Pharm. Bull. 1982, 30, 196-201. [CrossRef] [PubMed]

25. Rasmussen, S.; Wolff, C.; Rudolph, H. Compartmentalization of Phenolic Constituents in Sphagnum. Phytochemistry 1995, 38, 35-39. [CrossRef]

26. Fillion, E.; Dumas, A.M.; Kuropatwa, B.A.; Malhotra, N.R.; Sitler, T.C. Yb (Otf) 3-Catalyzed Reactions of 5-Alkylidene Meldrum's Acids with Phenols: One-Pot Assembly of 3, 4-Dihydrocoumarins, 4-Chromanones, Coumarins, and Chromones. J. Org. Chem. 2006, 71, 409-412. [CrossRef] [PubMed]

27. Coyle, C.H.; Martinez, L.J.; Coleman, M.C.; Spitz, D.R.; Weintraub, N.L.; Kader, K.N. Mechanisms of $\mathrm{H}_{2} \mathrm{O}_{2}$-Induced Oxidative Stress in Endothelial Cells. Free Radic. Biol. Med. 2006, 40, 2206-2213. [CrossRef] [PubMed] 